"Volume 15, No. 2, Desember 2021"

\title{
MANAJEMEN MUTU TERPADU DI PESANTREN
}

\author{
Oleh: \\ Siti Aimah \\ IAI Darussalam Blokagung Banyuwangi \\ sitiaimah1@iaida.ac.id
}

\begin{abstract}
:
The purpose of this study is to find; planning, implementation, evaluation, follow-up, characteristics and impacts of quality standards on the application of integrated quality management in Pondok Pesantren Darussalam Blokagung and Pondok Pesantren Modern AlKautsar Banyuwangi. This study uses a qualitative approach to the data collection techniques used that are: observation, interviews and documentation. The data analysis technique uses interactive three models that are: data reduction, data presentation, conclusion drawing. The results of this research: first, the pattern of MMT application in pesantren is influenced by the typology of the education system used, but substantially has the same pattern of organizing, planning, implementing, monitoring and innovation. The pattern formed a cycle that repeated itself in the implementation of quality activities with the control of the person responsible for quality in collaboration with all stakeholders in the Islamic boarding school, especially the organizers of the managed educational activities; second, characteristics of MMT in pesantren that is focus on customers in providing satisfaction, total stakeholder involvement both internal and external in organizing quality activities, quality standards that are in line with customer desires, commitment of pesantren education service providers in supporting the improvement of quality culture, continuous improvement through improving quality standards in line with increasing customer expectations and innovation values of the quality of the pesantren so that the public is increasingly in demand, prospective students and users, the integration of education and dual graduation is now increasingly in demand by the community; third the impact of implementing integrated quality management in pesantren is improvement of quality culture that triggers public appeal, to register their children in Islamic boarding schools and increasing number of students in pesantren, the increasing recognition of the quality (education) of pesantren in the community.
\end{abstract}

Keywords: Manajemen Mutu Tepadu, Pesantren 


\section{A. Pendahuluan}

Pesantren sebagai salah satu lembaga pendidikan Islam selalu diharapkan mampu menciptakan manusia muslim yang berilmu pengetahuan tinggi, punya iman dan takwa sebagai pengendali dalam penerapan atau pengalamannya dalam kehidupan bermasyarakat. Karena pesantren merupakan suatu lembaga pendidikan Islam tradisional yang sampai sekarang masih dipercaya masyarakat sebagai pusat pendidikan Islam. Sebagai lembaga pendidikan keagamaan, pesantren mempunyai peranan penting dalam meningkatkan pembangunan, khususnya dalam pembangunan mental masyarakat. Oleh karena itulah pesantren sangat diharapkan dapat membekali peserta didiknya agar mampu berdaptasi dengan perkembangan zaman, namun tetap berpegang pada prinsipprinsip keagamaan yang menjadi karakternya dalam laku kehidupan bermasyarakat.

Pondok pesantren dalam perspektif historis dapat diposisikan sebagai satu eleman determinan dalam struktur piramida masyarakat Indonesia sementara di pihak lain, dinamika perubahan sosial yang terjadi dalam masyarakat niscaya pula berdampak pada dunia pesantren. Dalam dialektika saling mempengaruhi antara dunia kehidupan sosial dan dunia pesantren tersebut, eksistensi dan pengaruh pesantren terhadap kehidupan masyarakat akan sangat bergantung pada kemampuannya merespon dan menjawab tantangan perubahan sosial yang terjadi dalam kehidupan masyarakat sebab hakikat perubahan sosial memerlukan pengetahuan baru, keterampilan baru, dan tanggung jawab substansial terhadap nilai nilai masyarakat. ${ }^{1}$

Pesantren adalah lembaga pendidikan yang ciri-cirinya dipengaruhi dan ditentukan oleh pribadi para pendiri dan pimpinannya sehingga cenderung untuk tidak tidak mengikuti suatu pola tertentu. Keseluruhan tujuan penyelenggaran pendidikan pesantren mulai dari komponenkomponen ideologi agama, pengajaran dan kewiraswastaan serta hal-hal penting demi kesinambungan eksistensi lembaga kepesantrenan. Semua mencakup mulai dari kelompok belajar pedesaan yang kecil lewat bentukbentuk menengah yang beranekaragam sampai dengan pusat-pusat pendidikan berbeda-beda melalui tingkatan pendidikan sekolah dan perguruan tinggi serta ribuan pelajar dan mahasiswa dari semua tingkatan usia. $^{2}$

${ }^{1}$ Sulthon Mashud dan Moh. Khusnuridlo, Manajemen Pondok Pesantren, (Jakarta: Diva Pustaka, 2003), 110.

2 Manfred Ziemek, Pesantren dalam Perubahan Sosial (Jakarta: Perhimpungan

$196 \mid$ JURNAL LISAN AL-HAL 
Abdurrahman Wahid menyebut ada tiga pola pengembangan pada pesantren. Pertama, pola pendidikan keterampilan yang ditawarkan dan dikelola oleh kementerian agama. Kedua, pola pengembangan yang dirintis dan diprakarsai oleh LP3ES dalam kerjasama dengan berbagai lembaga, baik dari pemerintah maupun swasta, dari dalam negeri maupun luar negeri. Ketiga, pola pengembangan sporadis yang ditempuh oleh beberapa pesantren utama secara mandiri, berdasarkan persepsi dan aspirasi masing-masing pengelolanya. Ketiga pola tersebut telah berlangsung bertahun-tahun tanpa pengetahuan yang cukup tentang asal usul pesantren, eksistensinya sebagai lembaga pendidikan, fungsi kemasyarakatan yang dimilikinya, sistem nilai yang berkembang di dalamnya dan tempat yang sebenarnya dalam stratifikasi kehidupan masyarakat di pedesaan notabene mayoritas pesantren ada di dalamnya. ${ }^{3}$

Otoritas individu kyai sebagai pendiri sekaligus pengasuh pesantren sangat besar dan tidak bisa diganggu gugat. Faktor nasab atau keturunan juga kuat sehingga kyai bisa mewariskan kepemimpinan pesantren kepada putranya yang dipercaya tanpa ada komponen pesantren yang berani memprotes. Sistem alih kepemimpinan di pesantren seperti ini seringkali mengundang sindiran bahwa pesantren layaknya kerajaan kecil, dimana raja mewariskan kepemimpinannya pada putranya yang terpercaya. Kyai sebagai pemimpin pesantren, aktifitasnya selain mengajar para santrinya juga memberikan pelajaran keagamaan kepada masyarakat sekitar dalam bentuk ceramah yang biasa disebut pengajian atau majlis ta'lim, baik itu sifatnya harian, mingguan, bulanan maupun pada acara-acara tertentu, seperti pernikahan, maulid nabi, isra' mi'raj dan hari besar Islam lainnya. Pentingnya memilih pemimpin di pesantren oleh pendiri kepada penerusnya yang dipercaya adalah bagian dari upaya menjaga keberlangsungan pesantren, sesuai Hadits berikut. ${ }^{4}$

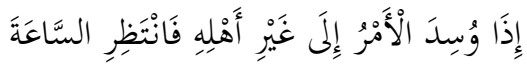

Artinya: apabila perkara diserahkan kepada orang yang bukan ahlinya maka tunggulah kiamat. (HR Al-Bukhari dari Abi Hurairah).

Selain itu dalam sistem kepemimpinan di pesantren, kyai meyakini bahwa kepemimpinannya adalah sebuah amanah yang membutuhkan pertanggungjawaban akhirat kelak, bukan hanya dalam kehidupan di

Pengembangan Pesantren dan Masyarakat, 1986), 97-98.

3 Abdurrahman Wahid, Menggerakkan Tradisi Pesantren (Yogyakarta: LKiS, 2010), $169-170$

${ }^{4}$ Saefulloh. Manajemen Pendidikan Islam (Bandung: Pustaka Setia, 2014), 128. 
dunia tapi juga kehidupan di. Oleh karena itulah ia sangat hati-hati dan menjalankan tugasnya dengan baik serta siap mempertanggungjawabkan tugas yang diembannya, termasuk dalam memberikan kepemimpinan pesantren kepada penerusnya, sesuai dengan sabda Rasullullah saw berikut. 5

$$
\text { كلكم راع وكلكم مسئول عن رعيته }
$$

Artinya: Setiap dari kalian adalah pemimpin, dan tiap-tiap pemimpin akan dimintai pertanggungjawabannya.

Hal yang paling menarik perhatian dalam pendidikan pesantren adalah program-program pendidikan dan pembangunan yang berorientasi tidak hanya bersifat agamawi melainkan pada komunitas yang mendasari pemahaman tentang gerak dan pengaruh pengajaran pesantren yang modern dan diperluas. Semua ini hanya bisa dilakukan oleh pengelola pesantren yang memiliki pengaruh besar. ${ }^{6}$

Menurut Horikoshi dalam penelitiannya tentang Kyai Yusuf Tajri menunjukkan bahwa kyai berperan kreatif dalam perubahan sosial. Hal ini berbeda dengan teori yang disampaikan Geertz bahwa kyai berperan sebagai makelar budaya " cultural broker" hanya sebagai penyaring arus informasi ke lingkungan santri, menularkan apa yang dianggap berguna dan membuang apa yang dianggap merusak. Horikoshi memperbaiki teori Geertz dengan menyebut peran kyai yang bukan hanya mencoba meredam akibat dari perubahan sosial tetapi justeru mempelopori perubahan sosial dengan caranya sendiri, tidak sekedar menyaring informasi melainkan menawarkan agenda perubahan yang dianggap sesuai dengan kebutuhan masyarakat yang dipimpinnya. Jadi kyai bukan menunda perubahan melalui penyaringan informasi, tetapi sepenuhnya berperan dalam perubahan sosial karena menyadari perubahan sosial bagian dari perkembangan yang tak bisa terelakkan lagi. Adapun cara yang digunakan adalah dengan memanfaatkan ikatan-ikatan sosial yang telah ada menuju mekanisme perubahan ideal bagi masyarakatnya. ${ }^{7}$

Pesantren sebagai lembaga pendidikan Islam harus mampu bersaing dalam menawarkan suatu model pendidikan kompetitif yang mampu

${ }^{5}$ Abu Abdullah bin Muhammad Ismail al-Bukharĩ, Sahih al-Bukhari, Kitab: Jum'at Bab alat Jumat di Desa dan Kota, No. Hadis : 844 (Beirut: Dar as -S a'bu, t.t), 139.

${ }^{6}$ Mukti Ali, H.A., The Ulama and Their Role in Development (A Study on The Rural Development in Java) dalam : Religion as a field of Study and Research, 2nd. Seminar Jakarta 1978. 110.

7 Abdurrahman Wahid dalam pengantar buku Kyai dan Perubahan Sosial karya Horikoshi (Jakarta: Perhimpunan Pengembangan Pesantren dan Masarakat, 1987), 17.

$198 \mid$ JURNAL LISAN AL-HAL 
melahirkan output (mutakharrijiin) santri yang mempunyai dasar alakhlaq al-karimah, serta memiliki kompetensi dalam penguasaan ilmu sekaligus skill (ketrampilan) sehingga mereka akan menjadi uswah alhasanah dalam kehidupan sosial masyarakat yang terus mengalami percepatan perubahan akibat modernisasi yang ditopang kecanggihan sains dan teknologi. Kegagalan pendidikan pesantren dalam melahirkan sumber daya santri yang memiliki kecakapan dalam bidang ilmu-ilmu keIslaman dan penguasaan teknologi secara bersinergi akan berimplikasi terhadap kemacetan potensi pesantren yang kapasitasnya sebagai salah satu agen perubahan (agents of change) dalam berpartisipasi mendukung proses transformasi sosial bangsa.

Pada perkembangannya, masyarakat pesantren memadu modernitas pendidikan dengan berbagai strategi. Sejak tahun 1998, pengelola pesantren telah berupaya memperkaya jenis-jenis ilmu pengetahuan dan SMP maupun SMA. Bahkan beberapa pesantren telah mengembangkan universitas. Upaya dalam meadukan modernitas dalam pendidikan itu ditujukan agar para santri mampu memiliki ilmu pengetahuan dan teknologi modern untuk kesejahteraannya dan masyarakat. ${ }^{8}$

Terkait dengan problem pendidikan pesantren dalam interaksinya dengan perubahan sosial akibat modernisasi ataupun globalisasi, kalangan internal pesantren sendiri sudah banyak melakukan pembenahan, mendirikan model pendidikan formal unggulan, seperti SD unggulan, MTs Unggulan, SMP Plus atau SMU, SMK, MA dan Perguruan Tinggi yang dikembangkan pesantren secara kompetitif dalam menarik minat masyarakat. Dengan dilakukannya pembenahan model pendidikan pesantren diharapkan terdapat semacam waranty atau jaminan kunggulan output (lulusan) yang siap bersaing dalam berbagai sektor kehidupan sosial. Pengembangan model pendidikan formal semacam ini telah menjadi trend di berbagai pesantren, akan tetapi harus dikelola dengan manajemen yang baik, karena hakikatnya dalam bahasa Arab manajemen diambil dari kata at-tadbir (pengaturan), kata ini merupakan devariasi dari kata dabbara (mengatur) yang banyak terdapat dalam al-Qur'an, diantaranya yaitu pada al-Qur'an Surah as-Sajdah ayat 5 berikut. ${ }^{9}$

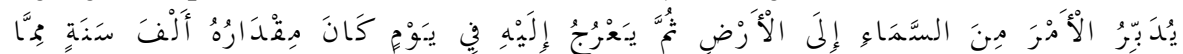

$$
\begin{aligned}
& \text { تَعَعُدُّونَ }
\end{aligned}
$$

Artinya: Dia mengatur urusan dari langit ke bumi, kemudian (urusan) itu naik kepada-Nya dalam satu hari yang kadarnya adalah seribu tahun

8 Zamakhsyari Dhofier, Tradisi Pesantren (Jakarta: LP3ES, 2015), 267.

${ }^{9}$ Saefulloh. Manajemen Pendidikan Islam (Bandung: Pustaka Setia, 2014), 1. 
menurut perhitunganmu.

Dari ayat di atas diketahui bahwa allah swt. adalah pengatur alam. Akan tetapi, sebagai khalifah di bumi, manusia harus mengatur dan mengelola bumi dengan sebaik-baiknya sebagaimana allah mengatur alam raya ini.

Untuk dapat memainkan peran edukatif dalam penyediaan sumber daya manusia yang berkualitas tersebut, pesantren seharusnya terus meningkatkan mutu (quality improvement) sekaligus memperbaharui model pendidikannya. Sebab, model pendidikan pesantren yang mendasarkan diri pada sistem konvensional atau salaf/klasik tidak akan cukup membentuk penyediaan sumber daya manusia yang memiliki kompetensi integratif baik dalam penguasaan pengetahuan agama, pengetahuan umum, dan kecakapan teknologi. Padahal, ketiga elemen ini merupakan pra syarat yang tidak bisa diabaikan untuk konteks perubahan sosial akibat modernisasi. Masyhud dan Ridlo mengemukakan tipe ideal model pendidikan pesantren yang banyak dikembangkan sekarang ini adalah tipe integral antara sistem pendidikan salaf/klasik dan sistem pendidikan modern. Pengembangan tipe ideal ini tidak akan merubah total wajah dan keunikan sistem pendidikan pesantren menjadi sebuah model pendidikan umum yang cenderung reduksionistik terhadap nilainilai yang terkandung dalam sistem pendidikan pesantren. ${ }^{10}$

Konsep Manajemen Mutu sangat berkembang dan banyak diterapkan, khususnya dalam dunia pendidikan. Mutu pendidikan (lulusan) tidak hanya ditentukan oleh seorang guru, tetapi oleh seluruh guru, juga pihak personalia sekolah, seperti pengelola dan staf administrasi. Mc. Laughlin menyebutkan bahwa manajemen mutu tidak sekedar suatu pendekatan atau strategi, tetapi lebih merupakan sistem bahkan suatu way of life untuk mencapai tujuan secara efisien agar dapat memenuhi tuntutan pengguna melalui penyempurnaan yang dilakukan secara terus menerus. ${ }^{11}$

Seiring dengan kebutuhan yang demikian cepat berkembang dan beragam serta kompleksitasnya masalah yang dihadapi pesantren, maka diperlukan adanya profesionalitas dalam rangka meningkatkan kualitas pendidikannya, khususnya pendidikan Islam. Lembaga pesantren perlu berbenah diri untuk dapat berhasil memenuhi kebutuhan dan tuntutan

10 Sulthon Mashud dan Moh. Khusnuridlo, Manajemen Pondok Pesantren, (Jakarta: Diva Pustaka, 2003), 115.

11 Nana Syaodih, dkk, Pengendalian Mutu Pendidikan Sekolah Menengah, (Bandung: Refika Aditama, 2008), 44.

$200 \mid$ JURNAL LISAN AL-HAL 
masyarakat modern tersebut. Pesantren sebagai lembaga dakwah sekaligus sabagai lembaga pendidikan yang mencetak generasi penerus Islam yang handal dan profesional sesuai dengan perkembangan jaman, dituntut untuk mampu menawarkan pemahaman Islam yang modern dan universal. Di samping modernisasi ide, modernisasi kelembagaan organisasi juga harus dilakukan dengan penerapan proses manajemen yang benar, dalam hal ini lebih ditekankan pada aspek manajemen pendidikannya.

Fokus dalam penelitian ini, yaitu: (1) Bagaimanakah Pola Manajemen Mutu Terpadu di Pondok Pesantren Darussalam Blokagung dan Pondok Pesantren Modern Al Kautsar Banyuwangi?; (2) Bagaimanakah Karakteristik Manajemen Mutu Terpadu di Pondok Pesantren Darussalam Blokagung dan Pondok Pesantren Modern Al Kautsar Banyuwangi?; (3) Bagaimanakah Dampak Penerapan Manajemen Mutu Terpadu di Pondok Pesantren Darussalam Blokagung dan Pondok Pesantren Modern Al Kautsar Banyuwangi?

\section{B. Tinjauan Teori}

1. Manajemen Mutu Terpadu (MMT)

Revolusi mutu menyebar baik di sektorbisnis maupun sektor publik selama tahun 1980-an dan 1990-an. Istilah umum yang digunakan untuk menggambarkan revolusi itu adalah Manajemen Mutu Terpadu/MMT atau Total Quality Management disingkat TQM. Revolusi itu diilhami oleh sekelompok kecil pakar mutu, yang paling menonjol adalah orang Amerika bernama W. Edward Deming dan Joseph M. Juran. Ide dan teknik yang didukung oleh kedua pria tersebut di tahun 1950-an mempunyai sedikit pendukung di Amerika Serikat (AS), tetapi secara antusias diterapkan pada organisasi di Jepang, ketika produsen Jepang mulai mengalahkan para pesaing dari AS dalam perbandingan utu, para manajer barat kemudian segera mulai melihat TQM dengan lebih serius lagi. Ide deming dan Juran menjadi dasar bagi program manajemen mutu organisasi sekarang ini. ${ }^{12}$

TQM In Education atau yang lebih kita kenal dengan Manajemen Mutu Terpadu/MMT adalah konsep manajemen pendidikan yang mengambil dari konsep manajemen industri dan dianggap perlu untuk diimplementasikan juga dalam dunia pendidikan. Secara lebih detail istilah MMT dideskripsikan sebagai filosofi atas perbaiakan yang kontinu

\footnotetext{
${ }^{12}$ Stephen P. Robbins \& Mary Coulter, Manajemen edisi kedelapan (Jakarta: Macanan Jaya Cemerlang, 2005), 50. 
serta memberikan rangkaian media praktis pada organisasi untuk pemenuhan harapan pelanggan, kini dan nanti. Ada beberapa hal yang harus dijalankan dalam MMT diantaranya adalah perbaikan terusmenerus, perubahan kultur, menjalankan organisasi terbalik (dari konsep tradisional), menjaga hubungan dengan pelangan, menjadikan kolega sebagai pelanggan, melaksanakan pemasaran internal, profesional dan fokus pada pelanggan, menjaga mutu pembalajaran dan mengelola kendala-kendala yang ada saat penerapan MMT untuk ditemukan solusinya. ${ }^{13}$

MMT sebagai konsep manajemen yang total dalam peningkatan mutu. Maka pada MMT mutu mutlak diutamakan dan mesti terus berlangsung perbaikan yang kontinu demi optimalisasi pencapaian mutu. ${ }^{14}$ MMT merangkai seluruh definisi konsep mutu; maka wajar jika MMT disebut sebagai manajemen mutu total. MMT juga menegaskan peran personil organisasi, etika, budaya, serta sistem mutu terarah untuk dapat dipastikan komitmen setiap anggota organisasi adalah hal yang dilakukan untuk perbaikan yang kontinu (Continous Improvement). ${ }^{15}$

Di Indonesia TQM dikenal dengan Manajemen Mutu Terpadu (MMT) sebuah langkah adalah pendekatan yang sistematis, praktis, dan strategis untuk penyelenggaraan pendidikan yang mengutamakan kepuasan pelanggandan berorientasi mutu. Definisi itu menegaskan bahwa peran penting komponen dalam sistem pendidikan yang berhubungan dengan input, proses dan output serta perangkat pendukungnya. MMT adalah alat pendekatan pada usaha untuk mencapai daya saing yang maksimal dengan cara melakukan inovasi tiada henti pada jasa, manusia, produk, dan lingkungan. ${ }^{16}$

Edward Sallis berpendapat: "Total Quality Management is a philosophy and a methodologhy wich assist institutions to manage change and set their own agendas for dealing with the plethora of new external pressures." (MMT adalah sebuah filsafat yang berkontribusi atas beragam institusi, khususnya industri yang bergerak di bidang perubahan dan

${ }^{13}$ Edward Sallis, Total Quality Management In Education (Yogyakarta: Diva Press, 2012), 73 .

14 S. Soimatul Ula, Buku Pintar Teori-Teori Manajemen Pendidikan Efektif (Yogyakarta: Berlian, 2013), 40.

${ }^{15}$ Agus Fahmi, Dkk, Konsep Pendidikan Modern (Surabaya : SMA Khadijah, 2006), 67.

${ }^{16}$ Husaini Usman, Manajemen Teori, Praktik, Dan Riset Pendidikan, (Jakarta: Bumi Aksara, 2006), 458.

$202 \mid$ JURNAL LISAN AL-HAL 
penyusunan program dalam menanggapi tekanan dari faktor eksternal yang dirasa berlebihan). ${ }^{17}$

MMT disebut juga sistem efektif yang dapat mengintegrasikan upaya-upaya pengembangan, pemeliharaan, dan perbaikan mutu dari beragam kelompok atau organisasi yang bertujuan untuk meningkatkan produktivitas dan pelayanan pada level paling ekonomis dalam memberikan kepuasan terhadap pelanggan. ${ }^{18}$ Oleh karena itulah bisa disimpulkan bahwa MMT adalah pendekatan pengelolaan organisasi dengan orientasi katkan untuk meningkatkan mutu produk atau jasa yang dihasilkan lembaga maupun institusi organisasi dalam rangkan memberikan kepuasan pelanggan. Dengan dasar itulah maka dalam MMT perlu ada tindakan yang bersifat perbaikan secara kontinu.

Untuk mewujudkan pendidikan yang bermutu dan berdaya saing tinggi, maka lembaga pendidikan harus menerapkan suatu konsep yang berorientasikan pada mutu. Konsep yang dimaksud adalah Manajemen Mutu Terpadu atau sering disebut dengan Total Quality manajemen (TQM). Dalam hal ini MMT lebih jauh membahas tentang bagaimana penerapannya dalam dunia pendidikan, khususnya di pesantren. Goetsch dan Davis dalam buku Total Quality Management mendefinisikan kualitas merupakan suatu kondisi dinamis yang berhubungan dengan produk, jasa, manusia, proses, dan lingkungan yang memenuhi atau melebihi harapan. ${ }^{19}$

Menurut Crosby mutu adalah sesuai yang disyaratkan atau distandarkan (Conformance to requirement), yaitu sesuai dengan standar mutu yang telah ditentukan, baik inputnya, prosesnya maupun outputnya. Oleh karena itu, mutu pendidikan yang diselenggarakan sekolah dituntut untuk memiliki baku standar mutu pendidikan. Mutu dalam konsep Deming adalah kesesuaian dengan kebutuhan pasar. Dalam konsep Deming, pendidikan yang bermutu adalah pendidikan yang dapat menghasilkan keluaran, baik pelayanan dan lulusan yang sesuai kebutuhan atau harapan pelanggan (pasar)nya. Sedangkan Fiegenbaum mengartikan mutu adalah kepuasan pelanggan sepenuhnya (full customer satisfaction). Dalam pengertian ini, maka yang dikatakan

${ }^{17}$ Edward Sallis, Total Quality Management In Education, Terj. Ahmad Ali Riyadi, Cet. Ke-4 (Yogyakarta: Ircisod, 2011), hlm. 33. Lihat Juga Dalam Agus Fahmi, Dkk, Konsep Pendidikan.... 68.

${ }^{18}$ Malayu S.P. Hasibuan, Manajemen Sumber Daya Manusia (Jakarta: Bumi Aksara, 2000), 219. 2001), 4 .

${ }^{19}$ Fandy Tjiptono Dan Anstasia Dian, Total Quality Manajemen (Yogyakarta: Andi, 
sekolah bermutu adalah sekolah yang dapat memuaskan pelanggannya, baik pelanggan internal maupun eksternal. ${ }^{20}$

Dari beberapa definisi pakar tersebut dapat disimpukan bahwa yang dimaksud dengan manajemen mutu adalah sebuah filosofi yang berisi konsep pelayanan terbaik kepada pelanggan sesuai apa yang diiginkan, diharapkan dan dibutuhkan pelanggan, sehingga mutu yang diberikan manajemen terkait dapat memberikan kepuasan pada pelanggan dan secara terus menerus meningkatkan standar mutunya menyesuaikan gerak dinamis keinginanan, harapan dan kebutuhan pelanggan dari masa ke masa.

MMT berfokus pada proses atau sistem pencapaian tujuan organisasi. Dengan dimulai dari proses perbaikan mutu, maka MMT diharapkan dapat mengurangi peluang membuat kesalahan dalam menghasilkan produk, karena produk yang baik adalah harapan para pelanggan. Jadi, rancangan produk diproses sesuai prosedur dan teknik untuk mencapai harapan pelanggan.

\section{Siklus Pemecahan Masalah Mutu}

Lingkungan pendidikan sangat kompleks sehingga butuh pendekatan sistematik dalam pemecahan masalahnya. Tidak seperti pemecahan masalah dalam bisnis seperti teori yang dikembangkan Deming yaitu PDCA (Plan, Do, Check and Act). Proses pemecahan masalah dalam pendidikan harus harus mengikuti urutan logis. Siklus pemecahan masalah mutu dalam pendidikan diawali dengan fase pengorganisasian mutu. Siklus ini berbeda dengan apa yang disampaikan Deming dalam bisnis yang dimulai dari fase apa saja. Karena siklus pemecahan masalah dalam pendidikan didesain untuk mengeliminasi masalah besar yang dialami banyak sekolah. Sangat banyaknya satuan tugas yang dibentuk menjadi masalah besar dan harus dihadapi sekolah yang secara signifikan tentu bisa menaikkan biaya implementasi mutu.

Mengorganisasikan mutu adalah fase yang memungkinkan sekolah memonitor dan melacak anggota dan kegiatan tim mutu yang ada. Selama fase ini, Komite Pengarah Mutu menentukan adanya kebtuhan pembentukan satuan tugas dan melacak jumlah satuan tugas yang dibentuk serta orag-orag yang ditugaskan pada masing-masing tim tersebut.

Perencanaan mutu sangat membantu sekolah dalam memastikan bahwa semua stakeholder yang terlibat dalam proses pemecahan masalah

${ }^{20}$ Crosby, Philip B., Quality Is Free (New York : New American Library, 1979), 58.

$204 \mid$ JURNAL LISAN AL-HAL 
mutu dan tim yang terlibat adalah orang-orang yang tepat dan bisa memberikan solusi yang tepat atas masalah yang dihadapi sekolah. Pada fase ini sangat memungkinkan sekolah membentuk struktur yang dapat membentengi atas adanya kemungkinan masalah tersebut muncul lagi.

Mengimplementasikan mutu, sepanjang fase ini tugas tim utamanya adalah memecahkan masalah, maka inilah fase paling populer dalam siklus pemecahan masalah. Fase ini dibagi menjadi 4 yaitu: cara tim memecahkan masalah, waktu pemecahan masalah, alasan pemecahan masalah dan rencana tindakan. Dalam fase ini masalah dianalisis untuk menentukan akar penyebabnya yang menghalangi proses untuk menghasilkan keluaran yang ideal. Kemungkinan pemcahan masalah dicari dan pemecahan masalah dibuat prioritas untuk memilih salah satu pemecahan masalah yang memberikan manfaat paling besar bagi pelanggan.

Satuan tugas mengidentifikasi kendala dalam menjalankan proyek mutu untuk memastikan bahwa penyelesaian masalah bisa memenuhi permintaan pelanggan maupun sekolah. Jika identifikasi telah dilakukan selanjutnya adalah mencari solusi. Selama melakukan langkah ini tim menyusun jadwal yang secara spesifik menyebut peyelesaian tugas-tugas terkait. Tim juga membuat kerangka langkah-langkah yang diambil dalam penyelesaian masalah dan mengidentifikasi patokan untuk tiap fase imlementasi. Jika tahap ini selesai tim siap menggambarkan bagaiamana masalah tersebut telah dipecahkan.

Monitoring mutu adalah fase terakhir dalam siklus pemecahan masalah. Pada fase ini tim memonitor hasil untuk memastikan hasil yang diinginkan. Fase monitoring mutu sering diabaikan. Begitu masalah terlah dipecahkan sekolah ingin secepatnya memproses masalah berikutnya. Akan tetapi kebanyakan sekolah tidak pernah membuktikan bahwa hasil yang diinginkan secara konsisten telah dicapai. Fase monitoring ini dalam siklus pemecahan masalah dimakali maksudkan untuk mencegah munculnya kembali masalah.

Tim menetapkan standar mutu dalam pemecahan masalah dan menggunakan lembar kerja monitoring mutu untuk memastikan bahwa proses benar-benar memberikan hasil yang diharapkan. Apabila proses secara konsisten memberikan hasil yang diinginkan, maka tim dapat melakukan 2 hal berikut: tim dapat dibubarkan dan atau tim dapat mengimplementasikan siklus perbaikan berkelanjutan.

Secara umum begitu satuan tugas menyelesaikan pekerjaannya dan setiap orang merasa puas dengan keluaran mutunya, maka satuan kerja tersebut dibubarkan. Akan tetapi sebelum satuan tugas menyelesaikan 
tugasnya, satuan tugas mendokumentasikan semua kegiatan dan menyerahkan dokumentasi tersebut pada Komite Pengarah Mutu. Pada beberapa hal satuan tugas harus memutuska untuk melakukan perbaikan lanjutan terhadap proses. Hal ini merupakan landasan siklus perbaikan berkelanjutan yang dalam penerapannya tim menaikkan standar mutu sampai tingkat tertinggi. Tujuannya mencakup hasil seperti pengurangan waktu, kesalahan dan orang yang terlibat.

\section{Karakteristik Sekolah (Lembaga Pendidikan) Bermutu Terpadu}

Pada dasarnya, sekolah bermutu memiliki 5 karakter stik, yang diidentifikasi seperti pilar mutu. Pilar-pilar berdasar atas kepercayaan, kerja sama dan kepemimpinan. Sekolah dengan mutu total pada implementasi mutu pendidikannya butuh komitmen yang baik atas upaya-upaya yang mendatangkan kepuasan terhadap pelanggan serta perlu perwujudan komitmen dalam penciptaan lingkungan yang mendukung seluruh staf dan siswa mampu melaksanakan pekerjaan dengan baik. Akan tetapi, sebelum implementasi pengembangan sekolah bermutu total, Hal yang mesti difahami adalah adanya hubungan dan keterikatan antar pilar.

Fokus pada kostumer. Kiranya sudah tepat saatnya memperkenalkan konsep mata-rantai pemasok/kostumer. Sebuah relasi terbangun antara harapan kostumer pada Anda dan apa yang anda harapkan dari pemasok. Inilah tanggung jawab kostumer anda untuk menidentifikasi keinginannya. Adalah tanggung jawab Anda untuk menerjemahkan keinginan kostumer tersebut kedalam spesifik pemasok. Anda tidak dapat memenuhi keinginan kostumer sekalipun pemasok anda memberikan bahan-bahan yang memenuhi keinginan Anda. Sayangnya konsep ini hilang dalam pendidikan; namun hal tersebut diterapkan dalam setiap proses pendidikan.

Keterlibatan total. Pada pilar ini seluruh anggota organisasi harus turut serta pada transformasi mutu. Dewan sekolah atau pengawas tidak satu-satunya yang harus bertanggungjawab atas mutu dan penyelenggaraannya, karena mutu mestinya menjadi tanggungjawab seluruh pihak. Kontribusi setiap anggota organisasi juga bagian dari hal yang dapat mewujudkan pelaksanaan mutu.

Pengukuran. Pilar ini banyak menjadi bagian dari sebab ketidakberhasilan penerapan mutu di sekolah. Saat ini banyak pakar yang terlibat pada penerapan mutu tetapi melupakan fokus pada pentingnya pegukuran sebagai bagian dari hal yang mesti ada pada kegiatan yang 
berorientasi peningkatan mutu. Artinya tanpa adanya standar atau pengukuran tentu tidak akan bisa melakukan pengukuran dalam evaluasi kegiatan mutu. Apalagi jika seklah tidak mampu memenuhi standar mutu yang ditetapkan atau diharapkan oleh masyarakat. Disinilah pentingnya standar atau pengukuran mutu. Nilai ujian contohnya, digunakan siswa untuk mengukur kemampuannya. Anggaran sekolah digunakan dalam pengukuran efisiensi kegiatan di sekolah.

Komitmen Pengawas Sekolah serta Dewan Sekolah sangat penting mempunyai komitmen terhadap pelaksanaan dan peningkatan mutu. Karena bisa dipastikan tidak akan pernah terjadi proses transformasi mutu jika pimpinan dan anggota organisasi tidak punya komitmen penerapan dan peningkatan mutu yang baik. Hal ini karena mereka harus mutlak mendukung upaya penerapan dan peningkatan mutu. Dalam pengertian lain mutu disebut dengan hal yang mampu merubah budaya dan cara kerja di suatu organisasi. Meskipun pada hakikatnya ada orangorang yang tidak menghendaki adanya perubahan tapi pengelolaan organisasi sangat memerlukan perubahan dalam bentuk dukungan implementasi mutu melalui rekomendasi pendidikan agar memiliki wacana yang baik tentang mutu, selain memberikan media, sistem dan proses pelaksanaan mutu.

Perbaikan berkelanjutan. Pada hakikatnya, sekolah harus mengadakan hal yang selalu lebih baik dari hari ke hari. Para pakar secara kontan juga perlu memberikan solusi yang tepat atas beberapa masalah yang mungkin muncul pada penerapan mutu dengan perbaikan proses yang berkelanjutan dan kontributif untuk peningkatan mutu lembaga atau organisasi.

Pertemuan dengan staf secara rutin dan berkala perlu dilakukan yang juga dengan menghadirkan siswa, orangtua serta komunitas masyarakat. Keterlibatan total, tanggungjawab pemecahan masalah dalam penlaksanaan sekolah bermutu total adalah pegawai. Umumnya, pegawai menunggu pimpinan atau pihak lain yang dianggap mampu mencarikan solusi alternatif. Pengukuran, Data adalah hal yang sangat diperlukan dalam pengukuran kegiatan mutu yang dikembangkan. Pengukuran yang menggunakan data tersebut juga dapat merekam peningkatan kegiatan mutu yang dilaksanakan, sehingga fokus selanjutnya adalah revisi atau inovasi.

Komitmen manajemen, seluruh manajemen baik di tingkat atas menengah maupun bawah harus punya komitmen berupa pelaksanaan pelatihan, sistem serta proses yang tentu diperlukan dalam merubah cara kerja yang lebih efektif efisien untuk perbaikan mutu serta peningkatan 
produktifitas ataupun layanan jasa. Perbaikan berkelanjutan, cara pandang dalam menghadapi masalah juga diperlukan untuk meminimalisir berbagai masalah yang bisa mengganggu perbaikan proses pendidik yang perlu dilakukan dengan cara konstan.

\section{Dampak dan Proses Pengembangan Mutu}

Sekolah bermutu merupakan lembaga pendidikan yang bekerja bersama pelanggan dan pemasoknya untuk memastikan siswa-siswanya dipersiapkan secara lebih baik untuk menghadapi masa depan. Maka dalam sekolah bermutu terpadu: (a) setiap proses pendidikan dapat diperbaiki; (b) setiap perbaikan besar maupun kecil berharga; (c) mutu terdiri atas langkah-langkah kecil menuju perbaikan dan setiap upaya diakui nilainya; (d) setiap orang bertanggungjawab untuk menjaga dan menyelesaikan masalah saat masalah itu muncul; (e) setiap orang diharapkan memberi sumbangan untuk proses perbaikan. ${ }^{21}$

Proses pengembangan mutu dimulai dengan pembentukan tim seperti pernyataan Deming dikutip Arcaro bahwa harus ada tujuan yang bersifat konstan. Seringkali sekolah beroperasi atas dasar manajemen krisis, sehingga menyebabkan adanya campur aduk dan prioritas dalam kegiatan perencanaan. Selain itu keluardan masuknya staf pengajar maupun staf administrasi bercampur baur menjadi masalah dalam mengejar keberhasilan implementasi berbagai program. Akibatnya, tidak ada "keajegan" dan tidak ada "tujuan" yang dinyatakan dengan jelas.

Melengkapi keajegan dan tujuan, model tersebut membantu dalam menerapkan proses yang diperlukan untuk mengimplementasikan upaya perbaikan di sekolah yaitu: menganalisis, membiasakan, mengkualitisasikan dan mengoptimalkan. Implementasi model tersebut terbagi ke dalam beberapa sub proses. Setiap sub proses dimulai dengan penjelasan outcome proses. Jika tepat, masing-masing proses akan diikuti dengan peragkat teknik yang bermanfaat untuk proses berlangsungnya kegiatan.

Mengembangkan fokus pada pelanggan, memahami pelanggan merupakan hal penting dalam proses mutu. Pendidikan merupakan usaha layanan kemanusiaan, pada umumnya mempunyai basis pelanggan yang bersifat captive. Maka dalam hal pelanggan internal maupun eksternal identifikasinya harus sudah jelas sejak dari awal. Tugas selanjutnya adalah upaya untuk memenuhi harapan dan permintaan pelanggan. Karena jika pelanggan tidak puas, maka sumberdaya akan sulit diperoleh dan

${ }^{21}$ Ibid. 145-161.

$208 \mid$ JURNAL LISAN AL-HAL 
dukungan akan berkurang. Meskipun bukan hal sia-sia perubahan akan diterima oleh orang-orang yang memiliki pengetahuan dan pemahaman terbatas terhadap kompleksitas yang terkait dalam bidang pendidikan.

Keyakinan dan Nilai-nilai, harus diartikulasikan dalam konsensus stakeholder. Kategorisasi keyakinan dan nilai-nilai merupakan cara efektif untuk memastikan bahwa semua bidang yang terkait telah dipertimbangkan. Daftar kategorinya antara lain: staf, sekolah, kurikulum, instruksi, siswa, orang tua, komunitas, kostumer, kinerja dan evaluasi.

Pernyataan Visi, membuat pernyataan visi hanyalah sekedar mengartikulasikan ke dalam satu alenia masa depan yang diinginkan oleh sistem sekolah, yakni satu hal yang secara signifikan lebih baik dari sekarang. Maka visi hendaknya didasarkan pada nilai-nilai dan keyakinan bersama. Pada proses ini hendaknya dimulai dengan para staf dan bagian administrasi lalu kemudian dibaas oleh badan pelaksana dan semua stakeholder.

Misi, tujuan pernyataan misi adalah mengartikulasikan cara untuk mencapai visi. Maka membuat pernyataan misi berarti membuat peta perjalanan sekolah untuk mewujudkan visi yang sudah ditetapkan sebelumnya.

Faktor-faktor Penting Keberhasilan, yakni mengidentifikasi targettarget yang penting untuk keberhasilan mencapai sebuah sasaran atau misi. Fokusnya adalah kegiatan tim pada tugas-tugas yang diperlukan dalam mencapai hasil yang diinginkan bersaa.

Tujuan dan Sasaran, merupakan tonggak yang dapat digunakan untuk mengukur efektifitas tim. Selain itu, tujuan dan sasaran mencerminkan fokus tim dalam memenuhi permintaan pelanggan. Tujuan dan sasaran juga memberikan fokus dan arahan bagi tim serta memungkinkan tim untk mengevaluasi manfaat dari outcome proyek mutu. Kelompok eksternal dalam pemahaman tim merupakan kelompok yang akan dipuaskan dalam rancangan kerja tim.

Pernyataan Manfaat Mutu, umumnya tim gagal membuat pernyataan mutu. Anggota tim dan manajemen beranggapan bahwa pelangga sudah tahu apa manfaat proyek mutu. Akan tetapi sebenarnya tidak demikian. Pada banyak hal tim perbaikan mutu sudah memperbarui proses namun outcomenya tidak memenuhi atau melampaui harapan pelanggan. Pernyataan manfaat mutu merupakan titik masuk lain pada proses perbaikan mutu. Pelanggan dapat dengan mudah meentukan apakah upaya tim perbaikan mtu berhasil atau sebaliknya. Hal ini jelas akan memberikan umpan balik yang berguna bagi tim sehingga bisa 
memastikan keberhasilan tim. Oleh karena itulah pernyataan manfaat mutu harus berkaitan erat dengan permintaan pelanggan.

\section{Pesantren}

Pesanren adalah asrama yang menjadi tempat tinggal santri/siswa yang belajar dan memperdalam ilmu agama Islam dengan pendampingan dan bimbingan langsung Kyai dan ustadz yang juga tinggal di lingkungan tersebut. Masjid menjadi bagian yang tidak terpisahkan dari santri dan kyai yang merupakan elemen pesantren, karena masjid menjadi tempat mengaji kitab-kitab klasik, shalat lima waktu dan shalat jum'at. Istilah santri yang menetap di pesantren terpilah menjadi dua yakni santri menetap/mukim dan santri tidak menetap/tidak mukim yang juga dikenal dengan istilah sanri kalong. Kyai merupakan elemen paling esensial dari sebuah pesantren. Jadi, elemen pesantren adalah pesantren (pondok/tempat tinggal santri), masjid, santri, kyai dan (pengajian) kitab klasik. ${ }^{22}$

Berbeda dengan Dhofier, Mastuhu menyebutnya dengan istilah unsur-unsur pesantren, dan membaginya menjadi 3 bagian: (1) Pelaku yang terdiri dari; Kyai, Ustadz, Santri dan Pengurus Pesantrean; (2) Sarana (Perangkat Keras) yang terdiri; Masjid, Rumah Kyai, Rumah Ustadz, Pesantren (Pondok, tempat tinggal santri) dan gedung sekolah; (3) Sarana (Perangkat Lunak) yang terdiri dari; tujuan, kurikulum dan sumber belajar berupa ktab-kitab dengan metode pembelajaran menggunakan sistem bandongan, sorogan, halaqah dan menghafal. ${ }^{23}$

Namun demikian, berbeda dengan pesantren di zaman modern, karena merasa mempunyai tuntutan untuk menyesuaikan diri dengan perkembangan zaman, maka metodologi pengajaran di pesantren telah berkembang. Hal ini disampaikan oleh Nur Efendi yang mengatakan bahwa pada awal mulanya pesantren menggunakan metode-metode tradisional yaitu sorogan, wetonan, muhawarah, mudzakarah dan majlis taklim, kemudian karena tantangan zaman modernitas maka pesantren juga menggunakan metode tanya jawab, diskusi, imla', muthala'ah, proyek, dialog, karya dan sebagainya. ${ }^{24}$

22 Zamakhsyari Dhofier, Tradisi Pesantren (Jakarta: LP3ES, 2015), 79.

23 Mastuhu, Dinamika Sistem Pendikan Pesantren (Jakarta: INIS Pustaka Nasional, 1994), 58

${ }^{24}$ Nur Efendi, Manajemen Perubahan di Pondok Pesantren (Yogyakarta: Teras, 2014), 132.

$210 \mid$ JURNAL LISAN AL-HAL 
Menurut Sulthon Masyhud dan Khusnurridlo bahwa perubahan yang terjadi dalam pesantren tidak tercerabut dari akar kulturnya dan tetap mempertahankan tradisi masalalunya dengan tetap mempunyai fungsi sebagai berikut: (1) lembaga pendidikan yang melakukan transfer ilmu agama Islam serta nilai-nilai di dalamnya; (2) lembaga keagamaan yang melakukan konrol sosial; (3) lembaga agama yang melakukan rekayasa sosial. ${ }^{25}$

Pesantren juga dikenal dengan lembaga pendidikan Islam serta lembaga dakwah Islam di Indonesia. Hal ini karena pesantren dibangun dengan keinginan bersama komunitas santri dan kyai yang rela mengajarkan ilmu agama Islam dan pengalamannya. Sesuai penuturan Imam Tholkhah dan Ahmad Barizi: "Kyai dan santri merupakan komunitas yang tergabung dengan kesadaran tinggi membangun peradaban keagamaan Islam di pesantren". 26

Dalam kajian lain, pondok merupakan madrasah dan asrama sekaligus yang menjadi tempat mengaji serta pembelajaran ilmu agama Islam. Adapun pesantren merupakan tempat tinggal santri yang belajar mengaji ilmu-ilmu agama Islam. ${ }^{27}$ Pada istilah yang populer, pesantren lebih disebut dengan pondok saja ada juga yang menggunakan gabungan istilah keduanya, yaitu pondok pesantren. Pada hakikatnya secara substantif istilah tersebut memuat makna sama dengan sedikit sekali perbedaan. Asrama yang menjadi tempat tinggal santri disebut dengan pembeda antara pondok dan pesantren. ${ }^{28}$

Pesantren pada umumnya juga merupakan komunitas kehidupan tradisional Islam yang bisa menjaga dan mewariskan keterkaitan tradisi Islam yang dibentuk oleh ulama dari waktu ke waktu tanpa batas periodik. Oleh karena itu, ketahanan lembaga pesantren agaknya secara implisit menunjukkan bahwa dunia Islam tradisi dalam segi-segi tertentu masih relevan di tengah deru modernisasi, meskipun bukan tanpa kompromi.

Menurut Adurrahman Wahid bahwa pola kehidupannya yang unik mampu menjadikan pesantren bertahan berabad-abad untuk mempergunakan nilai-nilainybertahan berabad-abad untuk mempergunakan nilai-nilainya sendiri. Karena itu, dalam jangka panjang

${ }^{25}$ Sulthon Mashud dan Khusnurridlo, Manajemen Pondok Pesantren dalam Prespektif Global (Yogyakarta: PRESSindo, 2006), 8.

26 Imam Tholhah dan Ahmad Barizi, Membuka Jendela Pendidikan (Jakarta: Raja Grafindo Persada, 2004)

${ }^{27}$ Purwodarminta, Kamus Umum Bahasa Indonesia (Jakarta: Balai Pustaka, 2006)

28 Suwendi, RA., Sejarah dan Pemikiran Pendidikan Islam (Jakarta:Raja Gravindo Persada, 2004) 
pesantren berada dalam kedudukan kulturil yang relatif lebih lebih kuat daripada kultur masyarakat di sekitarnya, tanpa ia sendiri mengorbankan identitas dirinya. ${ }^{29}$

Halim Soebahar ${ }^{30}$ menyebut pesantren sebagai media islamisasi nusantara yang bermula dari peran walisongo sebagai penyebar Islam di Indonesia. Hal ini berpatokan pada tiga unsur yaitu (1) ibadah untuk menanamkan iman; (2) tabligh untuk menyebarkan Islam; (3) ilmu dan amal untuk mewujudkan kegiatan sehari-hari dalam kehidupan bermasyarakat. Jadi pesantren didirikan oleh walisongo dan kyai dalam rangka penyebaran Islam dan ilmu pengetahuan umum.

Pesantren dalam hakikatnya, muncul sebagai perwujudan atas dua keinginan yang berpadu yaitu keinginan santri notabene orang yang ingin mencari ilmu agama yang lebih baik dan keinginan kyai merupakan orang yang secara ikhlas mengajarkan ilmu agama dan pengalaman spriritualnya kepada masyarakat. Pemilahan antara pesantren yang bertahan dengan sistem salaf dan pesantren yang mengadopsi sistem klasikal sekolah yang kemudian disebut pesantren khalaf/modern. Perubahan adalah sebuah keniscayaan dalam pesantren, khususnya sebagai lembaga pendidikan Islam. Allah swt. berfirman dalam al-Qur'an surah ar-Ra'du ayat 11:31

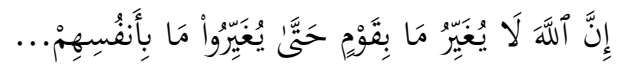

Artinya: sesungguhnya allah swt. tidak akan merubah nasib suatu kaum, sehingga kaum itu sendirilah yang akan merubah nasibnya sendiri.

Dalam ayat tersebut allah swt. menegaskan bahwa allah swt. sangat menghargai setiap upaya hambanya untuk melakukan perubahan menuju perbaikan yang bernilai lebih baik, maka pesantren sudah seharusnya diakui pemeritah dan masyarakat sebagai lembaga pendidikan Islam di Indonesia dengan fungsi utamanya sebagai lembaga tafaqquh fud-diin, pencetak kader ulama, calon guru agama Islam di madrasah khususnya harus bisa adaptif dan inovatif dalam sistem pendidikannya dengan prinsip: al-muhaafadhatu 'alaa al-qadiimi as-shaalih wa al-akhdu bi aljadiidi al-ashlah, artinya: mempertahankan radisi lama yang baik dan mengadopsi tradisi baru yang lebih baik. Dalam konteks pembaruan

\footnotetext{
29 Abdurrahman Wahid, Pesantren dan Pembaharuan (Jakarta: LP3ES, 1974), 74.

30 A. Halim Soebahar, Modernisasi Pesantren; Studi Transformasi Kepemimpinan Kyai dan Sistem Pendidikan Pesantren (Yogyakarta: LKIS, 2013)

31 PP. Jam'iyatul Qurra' Wa al-Huffadz Nahdlatul Ulama, al-Qur'an dan Terjemahnya (Jakarta: Hati Emas, 2014), 249.

$212 \mid$ JURNAL LISAN AL-HAL
} 
manajemen pesanren prinsip ini dikenalkan oleh A. Halim Soebahar dengan istilah Continuity and Change. ${ }^{32}$

Di masa depan pesantren harus mampu menangkap perkembangan yang terjadi pada masyarakat modern, namun pesantren harus tetap berdiri dengan teguh di atas landasan tradisi masalalunya. Dari sudut pandang inilah maka pesantren bisa melihat bahwa ada elemen-elemen lama yang mungkin perlu untuk dibuang, kemudian memasukkan elemenelemen baru dengan nilai positif, terdapat kebiasaan-kebiasaan lama yang ditinggalkan dan lembaga-lembaga baru sudah mulai diperkenalkan. ${ }^{33}$

Ziemek $^{34}$ mengemukakan bahwa memahami perkembangan yang terjadi setelah kemerdekaan dengan penampilan perselisihan antara faham idiologi dan politik dalam pertentengan demikian maka pendidikan memainkan peran sangat strategis. Namun demikian sangat sulit memahami situasi perkembangan pendidikan berdasarkan agama Islam jika tanpa memperhatikan nilai-nilai yang berlaku. Peadagogik yang memang termasuk dalam bidang pendidikan sebagai alat dan cara dalam menyebarluaskan masyarakat nilai-nilai agama berdasar syariat Islam.

\section{Metode Penelitian}

Paradigma yang digunakan dalam penelitian ini adalah post positivistik. Sedangkan pendekatan penelitiannya menggunakan studi kasus yang menekankan pada kasus sebagai obyek yang holistik menjadi fokus penelitian, seperti yang dijelaskan oleh Creswell bahwa dalam studi kasus, kasus yang spesifik diteliti, seringkali dengan tujuan untuk meneliti isu atau persoalan dengan menggunakan kasus tersebut untuk mengilustrasikan kompleksitas dari persoalan yang diteliti. ${ }^{35}$

Informan pada penelitian ini adalah stakeholder internal (pengelola pesantren) dan stakeholder eksternal (pengguna jasa pendidikan pesantren). Informan dipilih karena mempunyai kemampuan dan pemahaman terhadap kondisi Pondok Pondok Pesantren Darussalam Blokagung dan Pondok Pesantren Modern Al Kautsar Banyuwangi, khususnya yang terkait dalam adopsi dan implementasi MMT pada objek penelitian secara mendalam.

32 A. Halim,. Soebahar. Kebijakan Pendidikan Islam dari Ordonansi Guru sampai UU Sisdiknas (Jakarta : Raja Grafindo Persada, 2013), 182.

${ }^{33}$ Zamakhsyari Dhofier, Tradisi Pesantren (Jakarta: LP3ES, 2015), 281.

${ }^{34}$ Manfred Ziemek, Pesantren dalam Perubahan Sosial (Jakarta: P3M, 1986), 10.

${ }^{35}$ Ibid., 171. 
Adapun jenis data dalam penelitian kualitatif ini dikategorikan menjadi dua yaitu data penelitian primer dan sekunder ${ }^{36}$. Bagi peneliti jenis penelitian kualititatif penting untuk menemukan data primer berupa kata-kata (ucapan langsung/lisan) yang besifat verbal, bisa juga dengan perilaku subjek/informan penelitian yang masih terkait tema penelitian yaitu manajemen mutu terpadu di pesantren. Sedangkan data sekunder bisa diperoleh peneliti pada dokumen, foto dan arsip yang tujuannya mendukung data primer. Intinya data sekunder bisa berupa tulisan, rekaman dan dokumentasi yang masih terkait tema penelitian, yakni manajemen mutu terpadu di pesantren.

Data primer terkait manajemen mutu terpadu di pesantren yang diperoleh dari wawancara yaitu: (1) pemahaman manajemen mutu terpadu oleh pengelola pesantren; (2) latarbelakang penerapan manajemen mutu terpadu di pesantren; (3) pengadopsian manajemen mutu terpadu di pesantren; (4) penerapan manajemen mutu terpadu di pesantren; (5) faktor pendukung dan penghambat penerapa manajemen mutu terpadu di pesantren; (6) siapa saja yang terlibat pada penerapan manajemen mutu terpadu di pesantren; (7) standar mutu pendidikan di pesantren; (8) standar mutu lulusan pesantren; (9) evaluasi penerapan manajemen mutu terpadu di pesantren; (10) siapa saja pengendali mutu pendidikan pesantren; (11) apa saja tugas pengendali mutu pesantren pesantren; (12) siapa saja yang terlibat dalam penerapan manajemen mutu terpadu di pesantren.

Sedangkan data primer yang diperoleh dari observasi: (1) pelaksanaan kegiatan pendidikan yang menerapkan manajemen mutu terpadu di pesantren; (2) fasilitas kegiatan pendidikan dalam penerapan manajemen mutu terpadu di pesantren; (3) rapat-rapat pengendali mutu dan pihak terkait dalam penerapan manajemen mutu terpadu di pesantren.

Data Sekunder tentang manajemen mutu terpadu di pesantren yang didapat dari dokumentasi diantaranya; (1) sejarah pesantren; (2) struktur dan personalia pengurus pesantren; (3) jumlah santri; (4) prestasi pesantren dan santri; (5) fasilitas pendidikan; (6) SOP mutu; (7) peraturan dan kebijakan mutu.

Penelitian ini menggunakan jenis data kualitatif yakni data yang diperoleh dari hasil wawancara langsung dengan informan serta pengamatan atas perilaku informan terkait tema penelitian dalam bentuk

${ }^{36}$ Suharsimi Arikunto, Prosedur Penelitian; Suatu Pendekatan Praktik, (Jakarta: Rineka Cipta, 2006), 172.

$214 \mid$ JURNAL LISAN AL-HAL 
tertulis melalui analisis dokumen atau respon atas hasil survei ${ }^{37}$. Adapun data terpilah menjadi data utama dan tambahan didapat dari wawancara, catatan lapangan, pengamatan, gambar, rekaman suara, rekaman videon, dokumen pribadi, nota kesepahaman serta dokumen resmi ${ }^{38}$.

Penelitian ini menggunakan prosedur pengumpulan data seperti yang dikemukakan oleh Yin bahwa terdapat enam bentuk pengumpulan data dalam studi kasus yaitu: (a) Dokumentasi; (b)Rekaman arsip; (c) Wawancara biasanya bertipe open-ended; (d) Observasi langsung; (e) Observasi partisipan; (f) Perangkat fisik atau kultural

Penelitian ini menggunakan rancangan studi multikasus, maka dalam menganalisis data dilakukan dua tahap, yaitu: Analisis data kasus individu ${ }^{39}$ dan Analisis data lintas kasus. Pemeriksaan Keabsahan data pada penelitian studi kasus ini menggunakan penelitian pendekatan kualitatif sesuai pendapat Yin yang mengajukan empat kriteria keabsahan dan keajegan yang diperlukan dalam suatu penelitian pendekatan kualitatif. 40 Empat hal tersebut sebagai berikut: (a) Keabsahan Konstruk (Construct validity) terdiri dari Triangulasi data, peneliti/pengamat, teori dan metode; (b) Keabsahan Internal (Intern validity); (c) Keabsahan Eksternal (Ekstern validity); (d) Keajegan (Reability).

\section{Hasil Penelitian dan Analisis}

Pertama, Pola MMT yang diterapkan di pesantren, baik yang ada di Pondok Pesantren Darussalam Blokagung maupun Pondok Pesantren Modern Al Kautsar secara substansi sama yakni terdiri dari pengorganisasian, perencanaan, implementasi, monitoring dan inovasi. Meskipun demikian keduanya memiliki perbedaan yang disebabkan oleh latarbelakang tipologi dari sistem pendidikannya. Pondok Pesantren Darussalam Blokagung menggunakan sistem pendidikan terpadu sedangkan Pondok Pesantren Modern Al Kautsar menggunakan sistem pendidikan modern. Perbedaan sistem pendidikan inilah yang kemudian memunculkan kecenderungan perbedaan dalam penerapan pola MMT di masing-masing pesantren tersebut. Meskipun secara prinsip munculnya

\footnotetext{
${ }^{37}$ Ruslan Ahmadi, Metodologi Penelitian Kualitatif (Malang: UIN Press, 2005), 63.

38 Robert C. Bogdan dan San R. Biklen, Qualitative Research for Education: An Introduction to Theory and Method, (Boston: Allyn and Bacon, 1982), 2-3.

${ }^{39}$ Miles, M.B, Huberman, A.M, and Sadana, J. Qualitative Data Anaysis, A. Methods Soucebook, Edition 3. USA: Sage Publication. Terjemahan Tjetjep Rohindi Rohidi (UI-Press, 2014), 14.

${ }^{40}$ Ibid.
} 
perbedaan itu juga diimbangi dengan adanya persamaan-persamaan diantara keduanya.

Pada pola pengorganisasian kedua pesantren sama-sama mempunyai penanggungjawab kegiatan manajemen mutu pada pelayanana jasa pendidikan. Walaupun dengan nama berbeda. Di Pondok Pesantren Darussalam Blokagung disebut dengan Tim Pengendali Mutu, sedangkan di Pondok Pesantren Modern Al Kautsar disebut dengan nama Dewan Direksi Mutu. Keduanya secara sinergi bekerjasama dengan penyelenggara kegiatan pendidikan yang dikelola di masing-masing pesantren dalam penerapan MMT mulai dari perencanaan sampai pada evaluasi serta inovasi kegiatan.

Beberapa temuan tersebut dapat diafirmasi dengan pendapat Sallis bahwa sinergi yang baik pada tim kerja yang harmonis dibutuhkan dalam upaya peningkatan mutu yang mengharuskan kerja keras dna dukungan semua pihak sebagai pendekatan terbaik. Selain itu tim efektif juga sangat dibutuhkan dan menentukan efektifitas kinerja di lapangan. Maka diperlukan poin-poin berikut dalam mendukung kinerja tim yangg efektif, yaitu: (1) peran anggota dengan definisi kerja yang jelas; (2) tim butuh tujuan yang jelas; (3) tim butuh sumberdaya dasar untuk beroperasi; (4) tim perlu mengetahui tanggungjawab dan batas wewenangnya; (5) tim perlu rencana kerja; (6) tim butuh aturan kerja; (7) tim perlu alat-alat kerja; (8) tim perlu mengembangkan sikap baik dan punya manfaat. John S. Oakland dikutip oleh Sallis menayampaikan bahwa kerja tim dalam sebuah organisasi merupakan komponen penting dari implementasi MMT, mengingat kerja tim akan meningkatkan kepercayaan diri, komunikasi, dan mengembangkan kemandirian. ${ }^{41}$

Pada pola perencanaan masing-masing pesantren, baik Pondok Pesantren Darussalam Blokagung maupun Pondok Pesantren Al Kautsar merencanakan kegiatan yang berorientasi pada pemenuhan harapan, keinginan dan kebutuhan pelanggan. Pada Pondok Pesantre Darussalam Blokagung dengan mengakomodir kebuuhan pelanggan dan statemen menjadikan pesantren sebagai market yang menyediakan ragam kebutuhan pelanggan dengan harapan memberikan kepuasan pada pelanggan. Sedangkan pada Pondok Pesantren Modern Al Kautsar dengan melakukan need assesment dengan harapan standar mutu yang didukung dengan kegiatan yang direncanakan dalam pelayanan jasa pendidikan tepat sesuai dengan harapan pelanggan, sehingga mereka puas pada

${ }^{41}$ Edward Sallis, Total Quality Management (TQM) in Education Terj. (Yogyakarta: Ircisod, 2012). 179.

216 JURNAL LISAN AL-HAL 
layanan yang diberikan. Tentu kegiatan yang direncanakan di kedua pesantren memiliki prioritas berdasar tipologi pesantrennya.

Sebagai pesantren yang menggunakan sistem terpadu, Pondok Pesantren Darussalam Blokagung merencanakan kegiatan prioritas yang menjadi kompetensi utamanya yaitu penguasaan dan pemahaman santri pada literatur kitab salaf, al-Qur'an serta kemampuan stantri mencapai standar mutu pada sekolah formal yang dikelola. Demikian juga dengan Pondok Pesantren Modern Al Kautsar sebagai pesantren modern merencanakan kegiatan prioritasnya yaitu penguasaan santri pada bahasa Ara dan Inggris dengan baik dan benar, selain juga lulus pada kriteria mutu minimal pada evaluasi sekolah formal yang dikelola yang didukung dengan sumberdaya memadai dan standar mutu yang ditetapkan sebelum perencanaan kegiatan mutu.

Temuan tersebut dapat diafirmasi dari pernyataan Sallis bahwa standar mutu memiliki peranan dalam MMT. Standar mutu pendidikan adalah bagian dari hal yang membuat pesantren diminati oleh pengguna jasa layanan pendidikan, disinilah eksistensi pesantren dipertahankan bahkan ditingkatkan dari level lokal, regional, nasional sampai internasional. Hal ini sebagaimana pendapat Sallis yang menyatakan bahwa standar mutu memiliki peran pada MMT, karena dengan standar tersebut organisasi pendidikan dapat memberikan pesan aktual yang potensial kepada pelanggan bahwa institusi menggunakan mutu secara serius bahkan kebijakan serta praktik-paktiknya sesuai standar mutu nasional dan global. ${ }^{42}$

Deming mengungkapkan seperti yang dikutip Tjiptono dan Diana bahwa diperlukan siklus untuk meghubungkan antara suatu produk atau jasa layanan kepada pelanggan dan untuk memfokuskan sumber daya semua departemen/bidang dalam suatu usaha kerjasama untuk memenuhi kebutuhan tersebut. Adapun tahap-tahap siklus Deming terdiri dari; (1) mengadakan riset pada pelanggan dan menggunkannya dalam perencanaan produk/jasa (plan); (2) Menghasilkan produk/jasa (do); (3) Memeriksa produk/jasa apakah sudah sesuai dengan rencana (check); (4) Memasarkan produk/jasa tersebut (act); (5) Menganalisis bagaimana produk/jasa tersebut diterima dalam hal kualitas, biaya, kriteria dan lainnya (analyze). ${ }^{43}$

Perencanaan strategis sangat mungkin butuh formulasi atas hal-hal

${ }^{42}$ Edward Sallis, Total Quality Management (TQM) in Education Terj. (Yogyakarta: Ircisod, 2012), 135 .

${ }^{43}$ Fandy Tjiptono dan Anastasia Diana, TQM (Yogyakarta: ANDI, 2003), 50. 
yang diprioritaskan pada perencanaan jangka panjang serta kemungkinan adanya perubahan lembaga berdasar pertimbangan yang bersifat rasionalitas. Strategi pada sebuah lembaga penting untuk terus mengambil peluang baru. Adanya upaya strategis tersebut tidak hanya berfungsi dalam hal pengembangan rencana lembaga. Signifikansi yang nyata adalah bahwa adanya rencana strategis itu menjauhkan perhatian manajer senior dari isu-isu harian dan menekankan pada sebuah pengujian kembali terhadap tujuan utama institusi dalam hubungannya dengan pelanggannya. ${ }^{4}$

Upaya-upaya atas penetapan standar mutu pendidikan di pesantren sebagai bagian dari perencanaan strategis terus dilakukan oleh pengelola pesantren dengan cara membangun bekerjasama yang baik, melalui komunikasi, koordinasi, interaksi dan integrasi baik dengan stakeholder internal maupun stakeholder eksternal. Tujuan dari upayaupaya tersebut adalah memenuhi harapan, keinginan dan kebutuhan pelanggan pada jasa layanan pendidikan pesantren. Hal tersebut seperti pendapat yang disampaikan Sallis bahwa MMT merupakan filosofi terkait perbaikan kontinu yang bisa memberikan alat yang bersifat praktis pada lembaga pendidikan untuk pemenuhan kepuasan pelanggan kini dan nanti. ${ }^{45}$

Pola Implementasi MMT pada Pondok Pesantren Darussalam Blokagung dan Pondok Pesantren Modern Al Kautsar adalah integrasi kegiatan pendidikan keagamaan, pengetahuan umum dan ekstra kurikuler yang dikelola oleh madrasah diniyah, sekolah formal dan pesantren. Tiga kegiatan pendidikan itu masing-masing punya standar mutu yang menjadi pra syarat kenaikan maupun kelulusan santri di masing-masing pesantren. Pada akhirnya santri di masing-masing pesantren tersebut cakap dalam ilmu agama, memiliki wawasan yang luas serta terampil dalam pengusaan soft skill maupun life skill. Tentu dengan adanya lembaga pendidikan berbasis agama dan berbasis pengetahuan umum santri bisa memiliki double graduate yang menjadi keunggulan lulusan pesantren yang diharapkan pelanggan dan pengguna lulusan.

Temuan tersebut menjelaskan bahwa ada kerjasama yang baik melalui integrasi, interaksi dan interkoneksi antar pengelola pesantren dalam pelaksanaan kegiatan pendidikan baik di pondok pesantren

${ }^{44}$ Edward Sallis, Total Quality Management in Education (Yogyakarta: IRCiSoD, 2012), 212. 2012), 73

45 Edward Sallis, Total Quality Management in Education (Yogyakarta: IRCiSoD, 218 JURNAL LISAN AL-HAL 
Darussalam Blokagung maupun Pondok Pesantren Modern Al-Kautsar Banyuwangi dalam penerapan manajemen mutu terpadu dalam rangka memenuhi keinginan, harapan dan kebutuhan pelanggan.

Hal itu selaras dengan pendapat Sallis yang mendefinisikan bahwa institusi pendidikan adalah pemberi jasa, meliputi; pemberian beasiswa, penilaian dan bimbingan bagi para pelajar, para orang tua serta para sponsor mereka. Para pelanggan terdiri dari bermacam-macam golongan yang diidentifikasi menjadi tiga yaitu: Pelanggan utama yakni pelajar yang secara langsung menerima jasa layanan pendidikan; Pelanggan kedua yakni orang tua, pemerintah daerah dan sponsor yang langsung memiliki kepentingan dengan individu maupun institusi; Pelanggan ketiga yakni pihak yang memiliki peran penting, meskipun tidak langsung, diantara; pemerintah dan masyarakat secara keseluruhan. Jadi, jika tujuan penerapan manajemen mutu terpadu adalah memenuhi kebutuhankebutuhan pelanggan, maka hal penting yang perlu diperjelas adalah kebutuhan dan keinginan siapa yang perlu diutamakan, dipenuhi dan diberikan? Tentu jawabannya adalah pelanggan dengan masing-masing tingkatannya tersebut. ${ }^{46}$

Sedangkan pendapat Deming yang dikutip Arcaro menyampaikan bahwa ada 14 butir yang merupakan penerapan prinsip-prinsip mutu pendidikan, kemudian disebut dengan hakikat mutu pendidikan dalam pengaruhnya atas keberlangsungan pengembangan budaya mutu melalui: (1) Penciptaan konsistensi tujuan, maksudnya konsisten atas pelayanan yang diberikan pada santri/siswa serta memberi motivasi lembaga pendidikan untuk bersang di tingkat global; (2) Menyerap filosofi mutu total, artinya sistem pendidikan di sekolah/lembaga pendidikan mesti siap berkompetisi global dan menjadikan stakeholder sekolah siap belajar hal baru yang mendukung revolusi mutu dengan cara bekerja secara efisien dan produktif; (3) Mengurangi kebutuhan pengujian, maksudnya memberi kesempatan pada lingkungan belajar untuk mengembangkan hasil kerja santri/siswa berkualitas melalui pengurangan kebutuhan pada ujian maupun inspeksi berbasis produksi massal; (4) Memberikan nilai upaya sekolah melalui cara baru, yakni dengan meminimalisir biaya total pendidikan serta bekerjasama dengan wali/orangtua santri/siswa serta beberapa lembaga yang mendukung perbaikan mutu; (5) Terus memperbaiki kualitas dan produktivitas maupun pengurangan anggaran; (6) Berprinsip pendidikan sepanjang hidup dengan melaksanakan

46 Edward Sallis, Total Quality Management in Education (Yogyakarta: IRCiSoD, 2012), 67. 
pelatihan untuk seluruh pegawai dan memberikan seperangkat hal yang dibutuhkan untuk memperbaiki proses kerja ; (7) Kepemimpinan dalam pendidikan, kepemimpinan mempunyai tanggungjawab memberikan arahan dan memahamkan visi misi institusi yang memuat mutu dan mempaktikkan prinsip-prinsip mutu; (8) Menyingkirkan perasaan takut, supaya kinerja lebih efektif; (9) Menghadapi tantangan melalui pengembangan strategi untuk peningkata mutu; (10) Mewujudkan budaya mutu, yakni tidak memberikan kesempatan pada orang atau kelompok orang atau kelompok orang menjadi tempat bergantungnya mutu; (11) Perbaikan proses, dengan cara solusi lebih diutamakan dibandngkan mencari kesalahan; (12) Membantu siswa untuk berhasil, dengan cara berorientasi pada kualitas bukan kuantitas; (13) Memegang komitmen, artinya seluruh stakeholder mampu memegang komitmen gerakan mutu di sekolah/lembaga pendidikan; (14) Bertanggungjawab, dengan cara memberi kesempatan seluruh stakeholder bekerja menyelesaikan transformasi mutu. ${ }^{47}$

Pola MMT Monitoring dan (Inovasi) di Pondok Pesantren Darussalam Blokagung dan Pondok Pesantren Modern Al Kautsar yaitu melakukan moritong dan evaluasi di akhir kegiatan pembelajaran secara rutin dan berkala dan melakukan tes kompetensi utama sebagai syarat kelulusan sesuai tipologi pesantren. Pada Pola Inovasi melakukan kegiatan follow-up atas hasil dari moritoring kegiatan mutu pendidikan sebagai bagian dari upaya peningkatan mutu, diantaranya adalah pemberian award bagi santri dan reward bagi pengurus pesantren, pembinaan santri berprestasi dan pendampingan santri kurang berprestsi di Pondok Pesantren Darussalam Blokagung serta remidi, pembinaan tes toefl dari pusat bahasa Unej dan ITS di Pondok Pesantren Modern Al Kaustar.

Beberapa temuan tersebut dapat diafirmasi dengan pendapat Sallis bahwa sistem mutu mesti butuh rangkaian feed back dengan mekanisme yang baik. Tujuannnya untuk menghasilkan hasil akhir program yang bisa dianalisis berdasar perencanaan. Proses evaluasi perlu fokus atas pelanggan dan mengekplor isu-isu berikut: satu, lembaga mampu mewujudkan kepuasan pelanggan-pelanggannya; dua, bagaimana cara lembaga meraih misi dn tujuan strategisnya. Disinilah diperlukan kepastian atas proses evaluasi bisa mengawasi tujuan institusional pada level-level berikut ini: (a) segera, bersifat harian, seringkali dalam nuansa informal; (b) jangka pendek, butuh cara lebih tersruktur dan khusus agar ada waktu untuk perbaikan mutu; (c) jangka panjang, dipimpin langsung

${ }^{47}$ Jerome S. Arcaro, Quality in Education (USA: St. Lucie Press, 1995), 85-89.

$220 \mid$ JURNAL LISAN AL-HAL 
oleh lembaga secara menyeluruh. Evaluasi ini juga diperlukan untuk dasar dalam memperbarui rencana strategis organisasi. ${ }^{48}$

Fungsi evaluasi atas setiap tahap berbeda. Karena itulah evaluasi sering difahami sebagai upaya preventif untuk mencari benar salah, selain itu juga dengan evaluasi mampu mewujudkan peningkatan kerja selanjutnya. ${ }^{49} \mathrm{Hal}$ itu menegaskan MMT sebagai sistem yang diakui efektif dalam integrasi upaya-upaya pengembangan, perawatan serta perbaikan mutu oleh organisasi, menyebabkan adanya peningkatan produktivitas dan pelayanan ke tingkat paling ekonomis untuk kepuasan pelanggan. ${ }^{50}$

Temuan-temuan dari pola MMT di pesantren mulai dari pengorganisasian, perencanaan, implementasi, monitoring dan inovasi, baik di Pondok Pesantren Darussalam Blokagung maupun di Pondok Pesantren Modern Al Kautsar tersebut setelah diafirmasi dengan beberapa pendapat pakar dapat disimpulkan bahwa pesantren sebagai lembaga pendidikan sangat baik untuk terus ditingkatkan mutunya, utamanya dengan mewujudkan budaya mutu melalui penerapan MMT di pesantren.

Institusi pendidikan bukan merupakan entitas dan tidak berubah. Lembaga pendidikan akan eksis selama dapat memberian tujuan yang mampu berkontribusi pada masyarakat. Jika dianalogikan pada kehidupan biologis, ia memiliki siklus kehidupan (life cycle) dengan empat tahapan yaitu: formasi, pertumbuhan, kedewasaan serta penurunan (kejatuhan) dan pembahruan (revitalisasi). Setiap tahapnya institusi diharapkan bisa berubah, beradaptasi dan berkembang. Disinilah MMT dengan perencanaan strategis jangka panjang serta keterlibatan karyawannya dalam upaya peningkatan berkesinambungan, mengandung makna tersendiri dalam menghadapi perubahan-perubahan dalam setiap tahapan. 51

Kedua, Karakteristik fokus terhadap pelanggan baik Pondok Pesantren Darussalam Blokagung maupun Pondok Pesantren Modern Al Kaustar memberikan pelayanan terbaik untuk dapat memberikan kepuasan pada pelanggan melalui kegiatan pendidikan terpadu yang terstandar mutunya didukung dengan penyedia layanan jasa pendidikan yang juga terstandar kompetensinya.

Pada karakteristik keterlibatan total baik Pondok Pesantren Darussalam Blokagung maupun Pondok Pesantren Modern Al Kaustar

48 Ibid. 236.

${ }^{49}$ Ibid. 238.

${ }^{50}$ Ibid., 33.

51 Edward Sallis, Total Quality Management in Education (Yogyakarta: IRCiSoD, 2012), 156. 
melibatkan stakeholder internal dan eksternal dalam penyediaan layanan jasa pendidikan yang bermutu di pesantren, mulai dari penetapan standar mutu pendidikan pesantren, perencanaan kegiatan sampai pada evaluasi kegiatan.

Pada karakteristik standar mutu baik Pondok Pesantren Darussalam Blokagung maupun Pondok Pesantren Modern Al Kaustar memiliki standar mutu sebagai dasar dalam kegiatan implementasi MMT di pesantren. Adapun perbendaan standar mutu yang ditetapkan di kedua pesantren tersebut berdasarkan atas komptensi utama dari latar belakang tipologi pesantren terpadu yang diterapkan di Pondok Pesantren Darussalam Blokagung dan pesantren modern yang diterapkan di Pondok Pesantren Modern Al Kautsar.

Pada karakteristik komitmen baik Pondok Pesantren Darussalam Blokagung maupun Pondok Pesantren Modern Al Kaustar mempunyai penyedia layanan jasa pendidikan yang komitmen pada peningkatan mutu pendidikan.

Pada karakteristik perbaikan terus menerus baik Pondok Pesantren Darussalam Blokagung maupun Pondok Pesantren Modern Al Kaustar melakukan kegiatan peningkatan mutu pendidikan dalam pelayanan jasa pada pelanggan, berupa sinergi yang solid dengan stakeholder internal dan eksternal dalam peningkatan layanan mutu jasa pendidikan serta megoptimalkan peran TPM sebagai penanggungjawab mutu internal pesantren melalui kegiatan studi banding dan pembuatan SOP kegiatan mutu di Pondok Pesantren Darussalam Blokagung.

Pada Pondok Pesantren Modern Al Kautsar berupa review kurikulum pendidikan secara berkala sebagai usaha untuk memberi kemudahan pada pelanggan dalam mencapai tiga ranah pendidikan yang telah ditetapkan sebagai tujuan pendidikan serta terus meningkatkan kerjasama dengan alumni di perguruan tinggi serta pengelola Perguruan Tinggi Negeri agar lulusan PPM Al Kautsar termotivasi melanjutkan kuliah didukung dengan mengajak santri penuh semangat praktik bahasa asing di luar negeri

Dari beberapa paparan data penelitian tersebut dapat diketahui bahwa baik pondok pesatren Darussalam Blokagung maupun PPM AL Kautsar Banyuwagi telah menerapkan manajemen mutu terpadu dengan karakteristik berbeda sesuai tipologi pesantrennya dan tentunya sesuai dengan tingkat pemahaman konsep manajemen mutu terpadu pengelolanya dalam pengadopsian dan implementasinya, akan tetapi secara umum kedua pesantren tersebut sangat terlihat nilai mutu yang 
dibangun yaitu integrasi pendidikan dan double graduated yang menjadi nilai jual layanan jasa pendidikan yang dikelola. 52

Arcaro menjelaskan bahwa sekolah bermutu terpadu didasari kenyataan bahwa setiap orang yang terlibat dalam proses pendidikan memiliki kemiripan keyakinan dan nilai-nilai. Kebanyak profesional pendidikan masuk dunia pendidikan karena ingin memberikan kontribusi bagi pertumbuhan dan perkembangan siswa. Sedangkan untuk menjadikan sekolah bermutu terpadu berarti harus mampu menjalin hubungan baik dengan pelanggan.

Pendidikan memberikan jasa yang berpotensi dapat memecahkan masalah penting yang ada pada masyarakat. Disinilah para profesional pendidikan diminta kontribusinya untuk mengembangkan cara baru, cara yang sudah diperbaiki dalam mengajar. Hasilnya sistem pendidikan mampu meluluskan siswanya yang siap berkompetisi dalam dunia bisnis dan dunia akademik mutakhir.

Ketiga, Dampak penerapan MMT di pesantren baik di Pondok Pesantren Darussalam Blokagung maupun Pondok Pesantren Modern Al Kautsar adalah peningkatan budaya mutu di pesantren yang menjadi sebab munculnya daya tarik masyarakat sebagai calon santri dan pengguna lulusan layanan jasa pendidikan pesantren, sehingga pesantren semakin banyak jumlah santrinya karena diminati dan dikenal masyarakat luas.

Beberapa temuan tersebut dapat diafirmasi dengan pendapat Arcaro bahwa mutu yang diarahkan pada pelanggan notabene penerapan konsep strategis pada lembaga pendidikan. Nilai utamanya erdasar keyakinan bahwa mutu pendidikan mesti bertambah baik, jika siswa mampu bertanggungjawab atas nilai-nilai pendidikan atas sugestinya sendiri sampai dia termotivasi menjadi berprestasi. Hal ini memuat konsep dengan niali-nilai sebagai berikut: (1) kualitas yang difokuskan pada pelanggan; (2) Kepemimpinan yang efektif; (3) perbaikan berkelanjutan; (4) partisipasi total; (5) cepat-tanggap; (6) rancangan dan pemeliharaan mutu; (7) pandangan jangka panjang; (8) manajemen berdasar fakta; (9) pembagian kemitraan; (10) tanggungjawab kontinuitas. 53

\footnotetext{
52 Jerome S. Arcaro, Quality in Education (USA: St. Lucie Press, 1995), 37.

${ }^{53}$ Ibid, 23.
} 


\section{E. Simpulan}

Pertama, Pola Penerapan Manajemen Mutu Terpadu di pesantren dipengaruhi oleh tipologi sistem pendidikan yang digunakan, akan tetapi secara substansi memiliki pola yang sama yaitu pengorganisasian, perencanaan, implementasi, monitoring dan inovasi. Pola tersebut membentuk siklus yang kembali berulang dalam penyelenggaraan kegiatan mutu dengan pengendalian dari penanggungjawab mutu yang bekerjasama dengan seluruh stakeholder yang ada di pesantren, khususnya penyelenggara kegiatan pendidikan yang dikelola.

Kedua, Penerapan Manajemen Mutu Terpadu di pesantren selalu punya karakteristik yang dibangun atas keyakinan penyedia layanan jasa pendidikan dalam kemampuan memberikan kepuasan pada pelanggan, kepemimpinan dan kerjasama yang baik dengan seluruh stakeholder serta kepercayaan pelanggan atas mutu pelayanan sesuai yang distandarkan. Karakteristik tersebut berkembang dari asalnya di dunia industri menyesuaikan dengan karakteristik pesantren yaitu: fokus pada pelanggan dalam memberikan kepuasan, keterlibatan total stakeholder baik internal maupun eksternal dalam penyelenggaran kegiatan mutu, standar mutu yang selaras dengan keinginan pelanggan, komitmen penyedia layanan jasa pendidikan pesantren dalam mendukung peningkatan budaya mutu, perbaikan yang kontinu melalui peningkatan standar mutu seiring meningkatnya harapan pelanggan dan inovasi nilainilai mutu pesantren agar semakin diminati masyarakat, calon santri maupun pengguna, yakni integrasi pendidikan dan double graduated yang sekarang semakin diminati masyarakat.

Ketiga, Dampak dari penerapan Manajemen Mutu Terpadu di pesantren adalah peningkatan budaya mutu yang memicu daya tarik masyarakat untuk mendaftarkan putra-putrinya di pesantren sehingga semakin banyak jumlah santri di pesantren juga semakin dikenalnya mutu (pendidikan) pesantren di masyarakat.

\section{DAFTAR PUSTAKA}

Ahmadi, Ruslan, Metodologi Penelitian Kualitatif. Malang: UIN Press, 2005. Aimah, Siti, Strategi Peningkatan Kualitas Pelayanan Pendidikan di Pesantren Darussalam Blokagung Tegalsari Banyuwangi. Dalam Jurnal Darussalam. IAI Darussalam Pers, Vol. 3., 2011.

Arcaro, Jerome S., Quality In Education: An Implementation Handbook, USA: St.Lucie Press, 2015. 
Cresswell. John W., Penelitian Kualitatif \& Desain Riset, Jakarta : Pustaka Pelajar, 2015.

Crosby, Philip B., Quality Is Free, New York : New American Library, 1979.

Dhofier, Zamakhsyari, Tradisi Pesantren, Jakarta: LP3ES, 2015.

Efendi, Nur, Manajemen Perubahan di Pondok Pesantren, Yogyakarta: Teras, 2014.

Fahmi, Agus, dkk., Konsep Pendidikan Modern, Surabaya: SMA Khadijah, 2006.

Halim, A. Soebahar, Kebijakan Pendidikan Islam dari Ordonansi Guru sampai UU Sisdiknas, Jakarta : Raja Grafindo Persada, 2013.

Halim, A. Soebahar, Modernisasi Pesantren; Studi Transformasi Kepemimpinan Kyai dan Sistem Pendidikan Pesantren, Yogyakarta: LKIS, 2013.

Hasibuan, Malayu S.P., Manajemen Sumber Daya Manusia, Jakarta: Bumi Aksara, 2000.

Mashud, Sulthon dan Moh. Khusnurridlo, Manajemen Pondok Pesantren, Jakarta : Diva Pustaka, 2005.

Mashud, Sulthon dan Moh. Khusnurridlo, Manajemen Pondok Pesantren dalam Prespektif Global, Yogyakarta: PRESSindo, 2006.

Mastuhu, Dinamika Sistem Pendikan Pesantren, Jakarta: INIS Pustaka Nasional, 1994.

Miles, M.B, Huberman, A.M, and Sadana, J., Qualitative Data Anaysis, A. Methods Soucebook, Edition 3. USA: Sage Publication. Terjemahan Tjetjep Rohindi Rohidi, Jakarta: UI-Press, 2014.

Mukti Ali, H.A. The Ulama and Their Role in Development (A Study on The Rural Development in Java) dalam : Religion as a field of Study and Research, 2nd. Seminar Jakarta, 1978.

Nasution, S., Metodologi Penelitian Naturalistik Kualitatif, Bandung: Tarsito, 2003.

PP. Jam'iyatul Qurra' Wa al-Huffadz Nahdlatul Ulama, al-Qur'an dan Terjemahnya, Jakarta: Hati Emas, 2014.

Purwodarminta, Kamus Umum Bahasa Indonesia, Jakarta: Balai Pustaka, 2006.

Robbins, Stephen P. \& Coulter, Mary, Manajemen edisi kedelapan, Jakarta: Macanan Jaya Cemerlang, 2005.

Robert K. Yin, Case Study Research Design and Methods, Washington: COSMOS Corporation, 1989.

Rosyada, Dede, Paradigma Pendidikan Demokratis Sebuah Model Pelibatan Masyarakat Dalam Penyelenggaraan Pendidikan, Jakarta: Prenada Media, 2004. 
Saefulloh, Manajemen Pendidikan Islam, Bandung: Pustaka Setia, 2014.

Sallis, Edward, Total Quality Management In Education, Yogyakarta: Ircisod, 2012.

Suwendi, RA., Sejarah dan Pemikiran Pendidikan Islam, Jakarta:Raja Gravindo Persada, 2004.

Syaodih, Nana, dkk., Pengendalian Mutu Pendidikan Sekolah Menengah, Bandung: Refika Aditama, 2008.

Tholkhah, Imam dan Barizi, Ahmad, Membuka Jendela Pendidikan, Jakarta: Raja Grafindo Persada, 2004.

Tjiptono, Fandy dan Anstasia Dian, Total Quality Manajemen, Yogyakarta: Andi, 2001.

Usman, Husaini, Manajemen Teori, Praktik, Dan Riset Pendidikan, Jakarta: Bumi Aksara, 2006.

Wahid, Abdurrahman, Pesantren dan Pembaharuan, Jakarta: LP3ES, 1974.

Wahid, Abdurrahman, Menggerakkan Tradisi Pesantren, Yogyakarta: LkiS, 2010.

Ziemek, Manfred, Pesantren dalam Perubahan Sosial, Jakarta: P3M, 1986. 